\title{
The impact of OECD research on the education system of Kazakhstan
}

\author{
Yerbol Sarmurzin $^{1}\left[\right.$ Dazerke Amanzhol ${ }^{2} \cdot$ Kamshat Toleubayeva $^{2} \cdot$ Marina Zhunusova $^{2} \cdot$ Aray Amanova $^{1}$
}

Received: 3 March 2021 / Revised: 5 August 2021 / Accepted: 27 August 2021 / Published online: 13 September 2021

(c) Education Research Institute, Seoul National University, Seoul, Korea 2021

\begin{abstract}
In education, reform and renewal are constant. Policies are continually changing to meet the needs of the times and the society. Political advisors, such as the Organization for Economic Cooperation and Development, play an important role among private consultants as policy actors. According to Gunter's (in: Howlett and Mukerjee (eds), Handbook of policy formulation, Edward Elgar Publishers, 2017) classification of policy actors, the OECD can be classified as a supra-national organization. This paper examines the impact of OECD research on the education system of Kazakhstan. Based on the literature, the authors address two key issues-what role the OECD is performing in education policy reforms in Kazakhstan and whether this facilitates or undermines the provision of public education. The authors focus on the influence of Programme for International Student Assessment (PISA) as a global phenomenon, how Kazakhstan has embraced this international test, and how, even though PISA has made little or no difference to student outcomes, it is still credited for educational achievements.
\end{abstract}

Keywords OECD $\cdot$ PISA $\cdot$ Kazakhstan $\cdot$ Policy actors $\cdot$ Education

\section{Introduction}

Kazakhstan, like many other countries, participates extensively in international comparative research. An opportunity for a developing country such as Kazakhstan to set future benchmarks. The Programme for International Student Assessment (PISA) is one such test in which Kazakhstan is actively participating. Kazakhstan has taken part in four PISA exercises-2009, 2012, 2015, and 2018. The performance of Kazakhstani's 15-year-old students is not particularly impressive. Kazakhstan was not a member of the Organisation for Economic Cooperation and Development (OECD) when the PISA 2009 results were released in 2011. This paper aims to determine if the PISA findings changed Kazakhstan's educational system.

Education reform has been spreading globally. Levin (1998, p. 131) describes this as "a policy epidemic." As Ball (2003, p. 215) notes "this epidemic is 'carried' by powerful agents, like the World Bank and the OECD.” Bakvis (1997)

Yerbol Sarmurzin

yerbol.sarmurzin@gmail.com

1 L.N. Gumilyov Eurasian National University, 2, Kanysh Satbayev street, Nur-Sultan City, Kazakhstan

2 Buketov Karaganda University, Universitetskaya street 28, Karaganda city, Kazakhstan claims that "a quick glance at the crucial advisory space enveloping core executives in a number of countries suggests that this space is increasingly being populated less by key bureaucrats, pressure group representatives, and close partisan advisers and more by gurus from think tanks, polling firms, and management consulting organisations" (p. 85).

The OECD can be categorized as a supra-national policy actor (Gunter, 2017) that challenges the structure and range of education policies and programs around the world. Volante et al. (2017) note that the OECD's policy recommendations are largely based on the findings from their various international evaluations, such as the Teaching and Learning International Survey (TALIS), PISA, and the Programme for the International Assessment of Adult Competencies (PIAAC). Kazakhstan, as part of the global community, has been involved in all these studies, despite not being a member of the OECD. It must be emphasized that the OECD is widely seen as a body that has significant influence worldwide, including non-OECD countries. The establishment of the OECD Centre for Co-operation with Non-Members indicates the growing number of nations working within the OECD's sphere of influence across all the continents (Martens \& Jakobi, 2010; Sorensen et al., 2021).

A significant amount of research has been devoted to the impact of the OECD on global education policymaking (Sorensen et al., 2021). The effect of OECD policies varies 
significantly depending on the country, with each society reacting differently or having varied interpretations (Grek, 2009; Waldow \& Steiner-Khamsi, 2019; Wiseman \& Taylor, 2017). There is extensive literature on the impact of PISA on countries' education systems, with examples from nations such as Portugal (Marôco, 2021), Japan (Takayama, 2008; Takayama \& Lingard, 2021), Mexico (Moreno-Salto \& Robertson, 2021), Spain (Gomendio, 2021), and others. However, no such research has been conducted on Kazakhstan's educational system. Some papers include other aspects or statistical reports, but no full-fledged study exists.

This paper examines how OECD data have influenced Kazakhstani education policy and whether resulting policy measures have improved or hindered Kazakhstan's national education system. To bring more informed conclusions about PISA's role in educational contexts, a structured analysis of the literature on this topic was conducted. This included reviewing PISA national reports and official documents and compiling a database of scientific research papers, books, and research on PISA.

This paper begins with a discussion of methodology, followed by a brief explanation of PISA — what it measures, its procedures, and so on-and Kazakhstan's experience with the test. The paper concludes with the findings.

\section{Methods}

A systematic literature review has been used to inform this paper's arguments vis-a-vis the OECD's influences on the education system. The data had to meet two criteria for inclusion in the review: (a) report initial research results and (b) focus on the use of OECD research in educational settings, particularly PISA results.

There are several reasons for using a literature-based approach. First and foremost, as Cohen et al. (2013) point out, appropriate research techniques should be used according to the research goals. A literature-based approach is the most suitable method for this study because it "increases understanding and knowledge" (Cohen et al., 2013, p.157). In addition, this paper compares international research and how it affects Kazakhstan's secondary education. In light of Cohen et al. (2013) advice, researchers should employ all the resources they have access to. Library and internet sources provided sufficient material on the research question of this paper.

Official documents, books, and journal articles were the primary sources of information. There were several reasons for using these resources. Documents are an easily accessible database, whereas high-quality books can offer both an outline of a field and an in-depth analysis of a single subject (Creswell \& Creswell, 2017). Peer-reviewed journal papers, in addition to books, offer scholarly material of a measurable quality (Bryman, 2016). The researchers undertaking nonempirical research may consider academic debates "particularly useful" (Winstanley, 2010) because such discussions facilitate a critical and dialectical perspective on the research topic.

All studies were evaluated using a coding sheet created after a preliminary review of 10 publications and official documents. Content analysis was used to classify basic themes in the descriptive data (Weber, 1990). The results obtained from the collections of research papers are discussed in this paper, along with the positive and negative effects of OECD research on Kazakhstan's education system.

\section{PISA and Kazakhstan}

PISA seeks to assess 15-year-old students' academic performance in reading, mathematics, and science. The test is noted for its focus on students' practical abilities to apply academic knowledge and skills in real-life circumstances, as well as assessing competence in solving tasks that are not specifically relevant to particular subjects or educational fields. PISA's research framework aims to determine the degree to which students have developed general problemsolving skills that can be used to function effectively in modern society (OECD, 2001).

The PISA report looks at the academic ability of 15 -yearold students. The test is given to this cohort because, at 15 , students have now begun making key choices about their future-i.e., whether to continue their studies or enter the workforce. Thus, determining the degree of expertise and skills that will be useful for students in later life, as well as assessing their capacity to acquire the knowledge required for a relatively smooth transition to the adult world, is feasible at this age.

The PISA tests were first administered in 2000 and are repeated every 3 years. The cyclical nature of the test enables participating nations to track students' educational achievements and the impact of any educational system reforms, develop policy directions in general secondary education and identify barriers to their implementation, and conduct analytical work in an international context and assist each country that participates. PISA's seventh cycle was completed in 2018.

Due to the COVID-19 challenges, OECD member countries agreed to postpone the PISA 2021 assessment to 2022 and the PISA 2024 assessment to 2025. PISA 2022 will focus on mathematics, along with a creative thinking component (OECD, 2018). PISA 2025 will be based on science, which will include a revised foreign language evaluation. In addition, it will also provide a new feature, Learning in the Digital World, which will assess students' ability to participate in self-directed learning through digital platforms. 
Kazakhstani students aged 15 years first took part in PISA in 2009. The PISA 2009 test included 470,000 15-year-olds from 65 countries. A probability-proportional-to-size sampling was used to select 15-year-old students from each country. A total of 5590 students from 200 educational institutions comprised the nationwide sample of Kazakhstani 15-year-olds (Amreeva et al., 2010). Many countries felt the so-called "PISA shock" when the first PISA results were announced. In Germany, the PISA findings in December 2001 had a "tsunami-like effect" (Gruber, 2006, p. 195). Kazakhstan itself was ranked 58th out of 65 participating countries, but this came as no surprise. Yakavets and Dzhadrina (2014, p. 48) point out that involvement in international research such as PISA was "the key strategic step towards entering the world education arena" for Kazakhstan. As the OECD notes, "PISA can assist countries in seeking to bring about improvements in schooling and better preparation for young people as they enter an adult life of rapid change and deepening global interdependence" (OECD, 2001, p. 3).

Literacy was PISA 's main focus in 2009. According to Kazakhstan's Ministry of Education and Science, local students had difficulty coping with multiple texts and struggled to find and use knowledge from different sources. This implied that the secondary education system in Kazakhstan was adequate for practical tasks but did not prepare students for real-life challenges (MoES, 2011). Amreeva et al. (2010) point out that Kazakhstan's low PISA 2009 results demonstrated that the goal set for secondary schools- to prepare students to think critically in everyday life-was not achieved, owing to the lack of attention given to the functional aspect of learning materials and unfamiliar knowledge-testing conditions. This was revealed while evaluating students' abilities to solve interdisciplinary life problems that required maneuvering in unfamiliar settings, recognizing essential facts and existing obstacles, formulating plans, resolving issues, and providing reasons for their solutions.

Thus, it was essential for Kazakhstan to examine deficiencies in the school curriculum so as being teaching in line with international standards. Following the announcement of the results, the school sector underwent significant reforms, which involved fundamental changes in the program materials, teaching methods, and learning benchmarks (Muratkyzy, 2020).

The first President of Kazakhstan, Nazarbayev (2012), in his annual address to the Nation, "Socio-Economic Modernization as Main Vector of Development of Kazakhstan," announced that the Government would develop a National Action Plan for 2012-2016 (NAP) aimed at improving the functional literacy of students. In this context, the tracking of academic skills, including the involvement of Kazakhstani students in international tests such as PISA and TIMSS, was a successful step in the right direction (Yakavets \& Dzhadrina, 2014).
The NAP for the Advancement of Student Functional Literacy was implemented in 2012 to strengthen functional literacy skills, promote creative thinking and problem-solving abilities, and ensure that students were equipped for lifelong learning. This strategy involves a range of steps, mainly the modernization of pedagogical principles, strategies, services, and curricula, as well as 10 reforms of the management system to provide schools with greater autonomy in the modification of curricula (Bokayev, 2016).

McLaughlin (2017) also notes that PISA made an impact on Kazakhstan education policy. After the PISA 2009 results, the Government introduced several changes to the school programs, benchmarked to the international standards of PISA 's highest performers and commissioning experienced professionals from the University of Cambridge to develop a revised curriculum.

However, Muratkyzy (2020) emphasizes that, prior to the PISA 2009 results, Kazakhstan's government had already taken some active measures to improve the education system by founding Nazarbayev Intellectual Schools in 2008 . Described as "agents of change," these were the first schools to introduce a revised curriculum developed by the Cambridge University team. The new comprehensive program sought to build higher-level thinking skills for students by rejecting the former content-driven curriculum. Raidt (2009) warns that PISA might be used more to legitimize changes already in train rather than establish a new education model. Incidentally, Takayama (2008) proposed a similar argument for Japan, noting that PISA findings were used to support the implementation of curriculum policy changes being discussed by the Ministry of Education long before the publication of the 2003 PISA data. In this regard, Vera Centeno (2021) observes that the OECD has managed to establish a crucial role on the global political landscape, not only by defining its own policies but also by helping others do the same. This suggests that policymakers will draw on the results of international research whenever it is strategically convenient to do so.

\section{Additional research of the OECD}

Although Kazakhstan's entire school system was the primary focus of these education reforms, the broader education sector was also impacted. For instance, the OECD Education Policy Committee recommended that Kazakhstan conduct an impartial review of the educational levels of the general adult population PIAAC and teachers TALIS in 2012. The review itself took 6 years; consequently, seven thematic assessments were made by the Ministry of Education and Science in partnership with the OECD. In 2013-2015, two projects were implemented (Abylkassymova, 2020): (i) a review of the national educational policy and (ii) a review to increase efficiency in the use of school resources. 
In addition, the second decade of the 2000s was marked by several reforms in Kazakhstan that required significant improvements in the curriculum, quality standards, and examinations. Consequently, pedagogical activities were planned to be more student-centered; subject content was revised in line with international best practices; and preparation for school and summative evaluations were introduced. The Government developed a trilingual program and allowed STEM teachers to teach their subject content in English language while working with high school students, as outlined in the State Program of Education and Science Development 2016-2019 (SPESD, 2016).

These were bold political initiatives to boost excellence, the country's PISA ranking, and the quality of the education sector (Abylkassymova, 2020; Muratkyzy, 2020). As Toybazarova and Nazarova (2018) note, international comparative studies had contributed to the modernization of Kazakhstan's education system. The country's involvement in these studies helped the government to collect reliable statistics and offered a practical evaluation of the successes and challenges of education in general.

As previously mentioned, an education development policy for 2016-2019 has been introduced, with the key goal of renewing the content of secondary education (SPESD, 2016).

Abylkassymova (2020) states that the renewal of educational content is, firstly, a revision of the services and teaching methods. In this connection, Kazakh pedagogy faces the challenge of fundamentally changing the content of school education on the basis of advanced international pedagogical practice. The modern curriculum model focuses on the practical literacy of schoolchildren, independent study, critical examination and evaluation, and the effort and capacity to identify non-standard alternatives.

The transition to new educational content, which began in 2016 in Kazakhstan, has been completed. In 2020, the updated content was fully adopted (SPESD, 2016, 2019). Consequently, to prepare children for primary education, the benchmarks for success in the delivery of pre-school and primary education programs were established. In the lower grades, teaching the script, reading, writing (including the alphabet), and early growth of children's social, life, and self-learning skills will be inculcated. The new education program provides STEM elements for the development of inventions, technological advances, mathematical modeling, programming, robotics, and primary technology preparation. To this end, additional training programs, extracurricular science, and field events are organized. In high school, selected subjects are taught in English.

The OECD and World Bank point out that Kazakhstan has instituted profound changes aimed at improving the education sector and is gradually attaining international norms and best practices. Reform proposals include the extension of the pre-school, the introduction of new financing structures (including a per capita funding scheme), the establishment of community centers to assist small-scale schools, more investment in educational facilities, and greater use of information technology in schools (OECD/The World Bank, 2015).

Considering international assessments and practices, along with commitments made and results achieved, Kazakhstan intends to continue the development of education and institute radical measures to improve the quality of education and science. The government has adopted the State Program of Education and Science Development of the Republic of Kazakhstan for 2020-2025, which focuses on problem-solving and developing the education and science system to improve competitiveness and bring the nation closer to the best practices of OECD countries. This state program is aimed at improving PISA results in 2022. The government's goal is to attain the following result in PISA 2022: mathematics-470 points; reading-440 points; sciences-465 points (SPESD, 2019). A comparison of Kazakhstan's results can be seen in Fig. 1.

All this demonstrated the great impact of OECD research on the National education system of Kazakhstan.

\section{Results and discussion}

\section{Does OECD enable or threaten the provision of education systems?}

According to Grek (2014), the OECD became a key policy actor mainly through its international tests and being a leading organization in the area of transnational administration in education. The starting point was the OECD's research on the design of evaluation criteria and the organization's influence was therefore primarily due to the development of its role in global comparative research. Martens (2007, p.42) characterizes this as "a scientific approach to political decision making."

Many countries recognize that education should be a primary focus of national policy and expend a lot of effort to improve the sector. Kazakhstan is no exception. The Kazakh government has demonstrated its commitment to the development of its education system by updating current regulations, introducing new legislation, and recognizing and enforcing best practices.

After the failure of PISA 2009, the Kazakh state actively engaged in improving the education system. Consequently, education performance in Kazakhstan improved significantly following PISA. This can be seen as a positive impact of PISA on the country's education system (Bokayev, 2016). In 2012, Kazakhstan moved up 10 places, from 59 to 49th, 


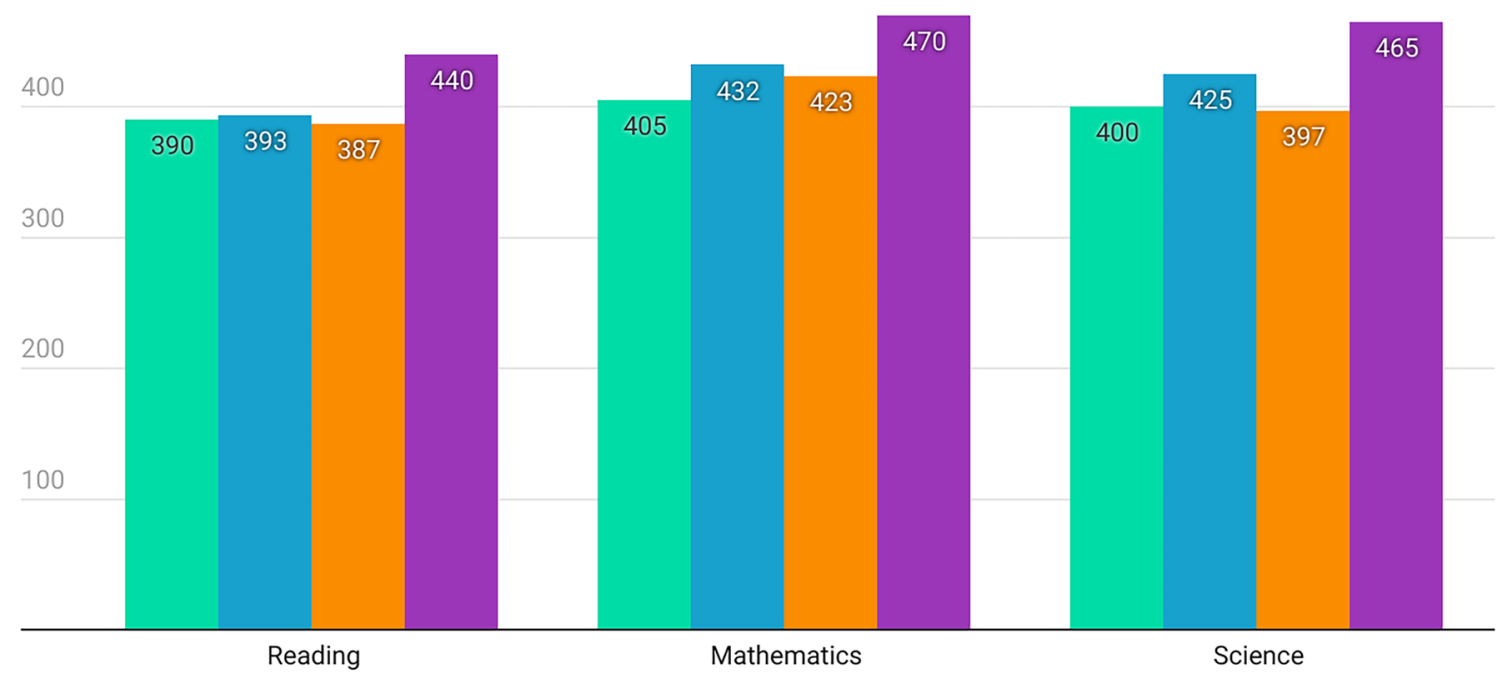

Created with Datawrapper

Fig. 1 PISA results of Kazakhstan

in the ranking of OECD participating countries in PISA (MoES, 2013).

However, these claims were made before the recent PISA results. The findings of PISA 2015 for Kazakhstan were not released "due to the potential of bias introduced by incomplete student-response data" (Avvisati et al., 2019, p. 3). There was a dramatic change in reading literacy outcomes for Kazakhstan in 2018 compared with 2009. Furthermore, in 2018, Kazakh students fared poorly in all three subject areas compared with 2012 (IAC, 2020). At first glance, these results imply that the new Kazakhstani education system is not quite as successful as intended (Fig. 1).

Despite the poor results, the Minister of Education and Science of Kazakhstan, Askhat Aimagambetov, argued that there are several reasons for the poor outcomes. He noted that the education reforms had not yet impacted on the 15-year-old students (children born in 2002). In addition, the Minister claimed that it was the first time that Kazakh children had taken a computer-based PISA test1. This meant that they could not refer to prior questions, unlike the paperbased exam (Kazpravda, 2019).

The Minister's final argument should be taken into consideration. According to Jerrim et al. (2018), the transition to computer-based testing may create unexpected challenges for students, such as "mode effects" on the comparison of PISA ratings. Such effects may make questions designed to be answered on paper systematically easier or harder when delivered via computer (2018, p. 477). Mode effects can be caused by a variety of factors, including variations in reading abilities between paper and display, test-taking practices, technological difficulties associated with computerized test administration in classrooms, and student involvement in the test (Jerrim, 2016). That administration of PISA saw a significant transition in 2015, with most countries switching from paper-based to computer-based evaluation. In this sense, Jerrim et al. (2018), using field trial PISA 2015 results from Germany, Sweden, and Ireland, investigated the effect of evolving evaluation modes on students' answers to pattern literacy, scientific, and mathematics questions initially intended for paper.

International Computer and Information Literacy Study 2018 (ICILS) demonstrates that the IT skills of Kazakh students are the lowest among the 14 countries (Fraillon et al., 2020). It is possible that low competence in information technology affected the results of computer-based PISA 2018.

One of the positive effects of PISA on the Kazakhstan education system can be seen in the chain of Nazarbayev Intellectual Schools (NIS). "The results of NIS have demonstrated the effectiveness of educational programs," says Minister Aimagambetov (Kazpravda, 2019). According to the Minister, NIS students achieved 511 points in reading comprehension, 554 points in mathematics, and 526 points in science. The data are compatible with the metrics of the top leaders of PISA 2018 (Fig. 2). Given that Nazarbayev schools are applying international best practices and their experience is spreading throughout the country (Shamshidinova et al., 2014), Kazakhstan's position may improve over time. As Andrews et al. (2014) note, lasting reforms in education practices take decades to materialize. 
Fig. 2 TOP 10 countries according to the PISA 2018 and NIS students' results

\section{[ Insert title here ]}

\begin{tabular}{|c|c|c|c|}
\hline \multirow[t]{2}{*}{ Mathematics $\square$ Science } & \multicolumn{3}{|l|}{ Reading } \\
\hline & Mathematics & Science & Reading \\
\hline China & 591 & 590 & 555 \\
\hline Singapore & 569 & 551 & 549 \\
\hline Macao & 558 & 544 & 525 \\
\hline Hong Kong & 551 & 517 & 524 \\
\hline Estonia & 523 & 530 & 523 \\
\hline Japan & 527 & 529 & 504 \\
\hline South Korea & 526 & 519 & 514 \\
\hline Canada & 512 & 518 & 520 \\
\hline Taiwan & 531 & 516 & 503 \\
\hline Finland & 507 & 522 & 520 \\
\hline $\begin{array}{l}\text { Nazarbayev Intellectual Schools } \\
\text { (Kazakhstan) }\end{array}$ & 554 & 526 & 511 \\
\hline
\end{tabular}

Foreign and local studies show the distinctive features of the traditional Kazakh school system, which relies more on the ability to recall rather than on the capacity to think. In Kazakhstan, however, topics are covered with an emphasis on theory, but less so on their practical implementation. Educational programs in the OECD states impact on the quality of student competencies (Abylkassymova, 2020). Meanwhile, these countries have experienced tremendous economic growth and, above all, a competitive advantage in their intellectual capital (Finland, South Korea, Japan, and others).

In this context, Kazakhstan has set itself the target of achieving a high standard of education by inculcating a new dimension to schooling. Kazakhstan is to transition from producing a "knowledgeable person" to nurturing an "individual who is able to think, perform, and improve creatively" through teaching that transforms from a traditional (knowledge-based) method to an innovation (competence) strategy. Therefore, the Ministry of Education and Science found it appropriate to establish a Compulsory Educational Standard (SCSES, 2012). Abylkassymova (2020) claims the new program, which is based on the PISA results, makes it possible to carry out an objective assessment of students' academic skills, motivation, and improvements in the educational process.

\section{Kazakhstan intends to be the world's most proficient reader}

The PISA 2018 results revealed that the reading literacy of Kazakhstani students decreased for the first time in 10 years. The first literacy score was 390 points, which rose to 393 , then dropped to 387 points at the end of 2018 (Fig. 1). This is 69 th out of 78 possible positions in the final ranking summary (OECD, 2019).

Consequently, improving students' reading skills was given a high priority. Addressing a meeting of the 4th session of the National Council of Public Trust, the Kazakh President, Kassym-Jomart Tokayev, emphasized the need to foster an interest in reading among students (akorda.kz, 2020).

The President states: "One of the objectives of the educational process in Kazakhstan's schools should be to promote a high reading culture and the development of reading literacy. Boys and girls in elementary school should develop an interest in reading and awareness of the surrounding world through reading books" (akorda.kz, 2020, unpaged).

Three areas were identified for improving students' reading literacy: modernization of school libraries, raising interest in reading, and applying innovative approaches to teaching literature.

Thus, on April 2, 2021, the Ministry of Education and Science adopted an integrated plan for the long-term development of libraries in educational organizations for 2021-2025 and for the implementation of the Readings School project (MoES, 2021) in accordance with the guidance given by President Tokayev. There are 6,461 schools with libraries in Kazakhstan. It was reported that over 40 million books from educational organizations and libraries were no longer suitable for use. Gani Beisembayev, the former director of the Uchebnik Scientific and Practical Center, states: "The library stock in the country's education system stands at above 200 million books, 39 million of which are literary and periodical publications. As for the quality, as 
some books were published in the 1980-1990s, about $20 \%$ of them are unusable now" (kazinform.kz, 2020, unpaged).

The Ministry of Education and Science makes efforts to replace old school library books and expand library collections as quickly as possible. It is estimated that it will take five years to complete this project. The annual development of book collections of school libraries is expected to increase by $20 \%$, according to the MoES' plan (kazinform.kz, 2020).

Additional modifications are being considered by the Ministry of Education (MES) for the curriculum of Kazakh literature in Grades 5 to 10 in the coming years. There are also some heated discussions on the topic of teaching world literature in schools (CSS, 2020).

It should be emphasized that the Minister of Education and Science, Askhat Aimagambetov, encourages reading among students. During the pandemic, the Minister appealed to the parents of Kazakh students to foster a passion for reading in their children from an early age. According to the Minister, the more children read outside of school, the easier it is for them to comprehend the curriculum (sputnik. $\mathrm{kz}, 2020$ ).

\section{How OECD research could threaten the national education system?}

PISA has been rigorously examined and roundly criticized by educational scholars around the world for the past 20 years. Zhao (2020) characterizes this period as "two decades of havoc." Several studies have shown that PISA has a significant impact on policy initiatives in many countries. This has reached the point where PISA has virtually become synonymous with the OECD: when addressing the OECD's impact on education, most academics refer to PISA (Seitzer et al., 2021). Inevitably, PISA is the subject of heated debate. Although Schleicher (2007, p. 356) argues that the PISA results give "policy-makers and practitioners helpful tools to improve quality, equity, and efficiency in education by revealing some common features in students, schools, and education systems that do well," OECD research could threaten the provision of public education. One of the critiques raised about the OECD in light of its global policymaking impact is that the organization is inherently politicized in favor of universalistic notions that can exacerbate current inequality between various regions and countries (Zurn, 2014). Therefore, Europe and North America, as well as a broader range of member States, could be seen as exerting disproportionate control over less developed places (Volante et al., 2017). Kazakhstan is a clear example of this, as the curriculum for a renewed education system has been prepared in collaboration with Cambridge University (Bridges, 2014).

Considering PISA's origins and governing structure, it should come as no surprise that the organization primarily focuses on evaluating OECD countries. Despite the historical emphasis on member nations, the number of PISA nonOECD participants now exceeds that of OECD members (Rutkowski \& Rutkowski, 2021). As shown by Rutkowski et al. (2019), there were significant variations in PISA 2015 performance across cultures, indicating that the PISA assessment may not be the best tool for measuring success across all the participating nations.

It is counterproductive if all countries adopt identical policies and practices irrespective of their local needs and backgrounds as education policies and practices are specific and culturally sensitive. It cannot even be guaranteed that so-called "policy borrowing" (Phillips \& Ochs, 2004) practices will be as effective in a different social and political environment as in the domestic contexts in which they were developed. In certain cases, what works in one situation is ineffective in another or, even worse, may even be pernicious (Harris \& Jones, 2015; Zhao, 2018, 2020). What is required of 15 -year-olds in one nation can vary significantly in another (Sjøberg, 2015).

In addition, PISA can impose another threat when it comes to curricula. The PISA assessments only cover certain aspects of education and only specific components within those subjects. They promote a "core and options" framework for curricula, "revering math, science, and reading" above other areas of education that some learners find more interesting (Starr, 2014). The same perspective is offered by Andrews et al. (2014), who claim that PISA does not address less explicit or non-measurable educational goals such as physical, spiritual, civic, and creative growth, thereby seriously limiting a common vision of the value of education. Kazakh researchers are also concerned that, by seeking high rankings in international research such as PISA or TIMSS, the government does not pay sufficient attention to arts, which have always been overshadowed by the hard sciences and social sciences (Semchenko, 2019). Consequently, national school programs no longer debate or focus on educational purposes but instead concentrate on improving PISA scores (Uljens, 2007).

Breakspear's (2012) report, which analyzed the policy responses of 37 countries to PISA, revealed that the impact ranged from negligible to exceptionally large. However, over $80 \%$ of the countries surveyed indicated some degree of influence on their education reforms. A more recent study undertaken by Volante (2016) with a group of scholars from Canada, the USA, England, Ireland, Scotland, Sweden, New Zealand, and the Netherlands was consistent with Breakspear (2012). Germany, for example, was especially reactive when considering changes and used PISA to modify the school system dramatically. PISA is widely credited with introducing evidence-based policy guidance within Germany through the implementation of national guidelines, centralized evaluations, and educational control mechanisms. There 
are many research studies (Arzarello et al., 2015; Grek, 2009; Gruber, 2006; Kuramoto \& Koizumi, 2016; and others) that actually identify certain countries that have been successfully changing their education systems by reviewing their PISA performance.

Nevertheless, some education experts point out that international studies have positive effects on national education. This is demonstrated by school reform in Kazakhstan, where radical changes were implemented. As Abylkassymova (2020) observes, in 2013-2015, the longitudinal study began with a change to 12 years of general secondary education in light of pending required school documentation specifying the teaching mode and materials adopted by the Ministry of Education and Science. Consequently, the weekly teaching load decreased by $1-3 \mathrm{~h}$ (to $36-39 \mathrm{~h}$ per week) compared with 11 years of education; key subjects were defined, which enabled individual students to select their own learning direction; and the standards for evaluating student comprehension were re-assessed.

Thus, the renewal of educational materials is aimed at meeting the key challenge of the school system-raising the standard of education and making the transition from "education for the whole life" to "lifelong learning." In addition, the authors' review of the modernization of the basic education system in Kazakhstan has shown that, as general secondary education is developing, the quality of secondary school education is also being enhanced, which enables Kazakhstani students to be educated under a modern system in sync with the world educational process (Abylkassymova, 2020).

\section{Limitations}

It is essential to note that there exist other possibilities and problems too numerous to cover in one paper. Further analysis is required to examine the claims presented here, as well as to provide evidence to various stakeholders.

\section{Conclusion}

From the foregoing, it may be observed that OECD research has mostly had a progressive impact on the national education system of Kazakhstan. The PISA results have significantly accelerated the process of updating the content of the school curriculum and moving toward the internationalization of Kazakhstani reform. It should be noted that many large-scale reforms in education in Kazakhstan were adopted before the PISA results. Therefore, it is erroneous to claim that the new system of education is based only on PISA. However, it should be emphasized that the OECD recommendations were considered during the modernization of the Kazakh education system. Although contemporary policy agendas could threaten the national school system of Kazakhstan, it is important for Kazakhstan to be involved in these studies to allow the education system to work for the prosperity of Kazakhstan by offering quality education to everyone. In the pursuit of ratings and attention from the educational powers, national values should be a priority.

\section{Notes}

The PISA 2018 reading evaluation was a computer-based assessment that was administered in the majority of the 79 countries that took part. Nine nations, however, used paperbased tools to test their students' knowledge and skills: Argentina, Jordan, Lebanon, the Republic of Moldova, the Republic of North Macedonia, Romania, Saudi Arabia, Ukraine, and Vietnam. For the first time in 2018, Albania, Georgia, Indonesia, Kazakhstan, Kosovo, Malta, Panama, and Serbia moved to a computer-based measurement.

\section{Declarations}

Conflict of interest The authors declared no potential conflicts of interest with respect to the research, authorship, and/or publication of this article. The authors received no financial support for the research and/ or authorship of this article.

\section{References}

Abylkassymova, A. (2020). System modernization of General Secondary Education in the Republic of Kazakhstan. Revista Tempos e Espaços Em Educação, 13(32), 46. https://doi.org/10.20952/ revtee.v13i32.13334

Akorda.kz. (2020). President Kassym-Jomart Tokayev attends the fourth meeting of the National Council of Public Trust [in Russian]. Retrieved 11 July, 2021, from https://www.akorda.kz/ru/ events/akorda_news/meetings_and_sittings/prezident-kasymzhomart-tokaev-prinyal-uchastie-v-chetvertom-zasedanii-nacio nalnogo-soveta-obshchestvennogo-doveriya.

Amreeva, T., Abdigapbarova, U., Azmaganbetova, Zh., Bazarbekova, Zh., \& Baigelova, N. (2010). National Report on the Results of the International PISA-2009 Study in Kazakhstan. National Center for Quality Assessment in Education.

Andrews, P. et al. (2014). OECD and PISA tests are damaging education worldwide-academics. The Guardian. Retrieved 22 January, 2021, from https://www.theguardian.com/education/2014/may/06/ oecd-pisa-tests-damaging-education-academics

Arzarello, F., Garuti, R., \& Ricci, R. (2015). The impact of PISA studies on the Italian National Assessment system. In K. Stacey \& R. Turner (Eds.), Assessing mathematical literacy (pp. 249-260). Springer.

Avvisati, F., Echazarra, A., Givord P. and Schwabe, M. (2019). Kazakhstan Country note. Results from PISA 2018. OECD. Retrieved 24 May, 2021, from https://www.oecd.org/pisa/publications/PISA2 018_CN_KAZ.pdf 
Bakvis, H. (1997). Advising the executive: Think tanks, consultants, political staff and kitchen cabinets. In P. Weller, H. Bakvis, \& R. A. W. Rhodes (Eds.), The hollow crown, countervailing trends in core executives (pp. 84-125). Macmillan Press.

Ball, S. (2003). The teacher's soul and the terrors of performativity. Journal of Education Policy, 18(2), 215-228. https://doi.org/ 10.1080/0268093022000043065

Bokayev, B. (2016) The improvement of the quality of primary and secondary education in Kazakhstan, Cornell University, Professional report. Retrieved from https://ecommons.cornell.edu/bitst ream/handle/1813/45565/Baurzhan\%20Bokayev\%20Professi onal\%20Report\%202016.pdf?sequence $=3 \&$ isAllowed $=y$

Breakspear, S. (2012). The Policy Impact of PISA: An Exploration of the Normative Effects of International Benchmarking in School System Performance. OECD Education Working Papers No. 71. Retrieved 20 January, 2021, from http://www.eunec.eu/sites/ www.eunec.eu/files/attachment/files/5k9fdfqffr28.pdf.

Bridges, D. (2014). Educational reform and Internationalisation: The case of school reform in Kazakhstan. Cambridge University Press.

Bryman, A. (2016). Social research methods (4th ed.). Oxford University Press.

CCS-Central Communications Service under the President of the Republic of Kazakhstan. (2020). With the guidance of the Head of State, several works have been launched as part of the Reading School project. Retrieved 24 May, 2021, from https:// ortcom.kz/en/novosti/memleket-basshysynyn-tapsyrmasymenkitap-oquga-qushtar-mektep-zhobasy-ayasynda-birqatar-zhumy star-qolga-alyndy

Centeno, V. (2021). The OECD: Actor, arena, instrument. Globalisation, Societies and Education, 19(2), 108-121. https://doi.org/10. 1080/14767724.2021.1882958

Cohen, L., Manion, L., \& Morrison, K. (2013). Research methods in education (8th ed.). Routledge.

Creswell, J., \& Creswell, J. (2017). Research design: Qualitative, quantitative and mixed methods approaches. Sage publications.

Fraillon, J., Ainley, J., Schulz, W., Friedman, T., \& Duckworth, D. (2020). Preparing for life in a Digital World: IEA International Computer and Information Literacy Study 2018 International Report (p. 297). Springer.

Gomendio, M. (2021). Spain: The evidence provided by International large-scale assessments about the Spanish Education System: Why nobody listens despite all the noise. In N. Crato (Ed.), Improving a Country's Education (pp. 175-201). Springer.

Grek, S. (2009). Governing by numbers: The PISA 'effect' in Europe. Journal of Education Policy, 24(1), 23-37. https://doi.org/10. 1080/02680930802412669

Grek, S. (2014). OECD as a site of coproduction: European education governance and the new politics of "policy mobilization. Critical Policy Studies, 8(3), 266-281. https://doi.org/10.1080/19460171. 2013.862503

Gruber, K.-H. (2006). The German 'PISA-Shock': Some aspects of the extraordinary impact of the OECD's PISA study on the German education system. In H. Ertl (Ed.), Cross-National Attraction in Education: Accounts from England and Germany (pp. 195-208). Symposium Books.

Gunter, H. (2017). Consultants and policy formulation. In M. Howlett \& I. Mukerjee (Eds.), Handbook of policy formulation (pp. 337-351). Edward Elgar Publishers.

Harris, A., \& Jones, M. (2015). Leading futures: Global perspectives on educational leadership. SAGE Publications India.

IAC. (2020). Achievements in reading, mathematics and science: Results of PISA 2018 in Kazakhstan, National Report. Information and Analytical Center.

Jerrim, J. (2016). PISA 2012: How do results for the paper and computer tests compare? Assessment in Education: Principles, Policy
\& Practice, 23(4), 495-518. https://doi.org/10.1080/0969594X. 2016.1147420

Jerrim, J., Micklewright, J., Heine, J. H., Salzer, C., \& McKeown, C. (2018). PISA 2015: How big is the 'mode effect' and what has been done about it? Oxford Review of Education, 44(4), 476-493. https://doi.org/10.1080/03054985.2018.1430025

Kazinform.kz (2020). Kazakhstan launches Reading School project. Retrieved 11 July, 2021, from https://www.inform.kz/en/kazak hstan-launches-reading-school-project_a3712860

Kazpravda, (2019). Results shown by Kazakh Students in the Global Study PISA-2018. Kazakhstanskaya Pravda. Retrieved 29 January, 2021, from https://kazpravda.kz/en/news/politics/resultsshown-by-kazakh-students-in-the-global-study-pisa-2018.

Kuramoto, N., \& Koizumi, R. (2016). Current issues in large-scale educational assessment in Japan: Focus on National Assessment of Academic Ability and University Entrance Examinations. Assessment in Education: Principles, Policy \& Practice, 25(4), 415-433. https://doi.org/10.1080/0969594X.2016.1225667

Levin, B. (1998). An epidemic of education policy: (What) Can we learn from each other? Comparative Education, 34(2), 131-142. https://doi.org/10.1080/03050069828234

Martens, K. (2007). How to become an influential actor-the 'Comparative Turn' in OECD education policy. In K. Martens, A. Rusconi, $\&$ K. Lutz (Eds.), Transformations of the State and Global Governance (pp. 40-56). Routledge.

Martens, K., \& Jakobi, A. P. (2010). Mechanisms of OECD governance: International incentives for national policy making? Oxford University Press.

Mclaughlin, C. (2017). Researching practice as education and reform. In M. A. Peters, C. Bronwen, \& I. Menter (Eds.), A companion to research in teacher education (pp. 583-597). Springer Singapore.

Marôco, J. (2021). Portugal: The PISA effects on education. In N. Crato (Ed.), Improving a Country's Education (pp. 159-174). Cham: Springer.

MoES-Ministry of Education and Science of the Republic of Kazakhstan. (2011). National report on the status and development of the Republic of Kazakhstan (Concise Version). The National Center for the Education Quality Assessment.

MoES-Ministry of Education and Science of the Republic of Kazakhstan. (2013). National Report on the State and Development of Educational System of the Republic of Kazakhstan, Astana.

MoES-Ministry of Education and Science of the Republic of Kazakhstan. (2021). The integrated plan for the long-term development of libraries in educational organizations for 2021-2025 and for the implementation of the project of the Readings School, approved by Vice-Minister Karinova 2 April 2021

Moreno-Salto, I., \& Robertson, S. L. (2021). On the 'life of numbers' in governing Mexico's education system: A multi-scalar account of the OECD's PISA. Globalisation, Societies and Education, 19(2), 213-227. https://doi.org/10.1080/14767724.2021.1880882

Muratkyzy, A. (2020). Equity and excellence in the Kazakhstani Education System: A multilevel analysis of the personal and contextual factors contributing to students' reading literacy performance on PISA 2018. (Unpublished Master dissertation). Nazarbayev University Graduate School of Education, Kazakhstan. Retrieved from https://nur.nu.edu.kz/handle/123456789/4886

Nazarbayev, N. (2012). Socio-Economic Modernization as Main Vector of Development of Kazakhstan. Address by the President of the Republic of to the Nation of Kazakhstan, January 27. Retrieved 24 May, 2021, from https://www.akorda.kz/en/addresses/addresses_ of_president/address-by-the-president-of-the-republic-of-kazak hstan-nursultan-nazarbayev-to-the-people-of-kazakhstan-27-012012_1341926486

OECD. (2001). Knowledge and skills for life: First results from the OECD Programme for International Student Assessment (PISA) 2000. OECD Publications. 
OECD. (2018). PISA 2021 mathematics framework (Draft). Retrieved 24 May, 2021, from https://pisa2021-maths.oecd.org/files/PISA\% 202021\%20Mathematics\%20Framework\%20Draft.pdf

OECD. (2019). PISA 2018 results (Volume I): What students know and can do. OECD Publishing.

OECD/The World Bank. (2015). OECD reviews of school resources: Kazakhstan 2015. OECD Publishing. https://doi.org/10.1787/ 9789264245891-en

Phillips, D., \& Ochs, K. (2004). Educational policy borrowing: Historical perspectives. Symposium.

Raidt, T. (2009). PISA: Katalysator im Bildungspolitischen Paradigmenwechsel. Dimensionen des Wertewandels im Bildungswesen (Unpublished doctoral dissertation). University of Stuttgart, Germany.

Rutkowski, D., \& Rutkowski, L. (2021). Running the wrong race? The case of PISA for development. Comparative Education Review, 65(1), 147-165.

Rutkowski, L., Rutkowski, D., \& Liaw, Y. L. (2019). The existence and impact of floor effects for low-performing PISA participants. Assessment in Education: Principles, Policy \& Practice, 26(6), 643-664. https://doi.org/10.1080/0969594X.2019.1577219

Schleicher, A. (2007). Can competencies assessed by PISA be considered the fundamental school knowledge 15-year-olds should possess? Journal of Educational Change, 8, 349-357. https://doi. org/10.1007/s10833-007-9042-x

SCSES. (2012). State Compulsory Secondary Education Standard (Primary, Secondary, General Secondary Education). Approved by the Decree of the Government of the Republic of Kazakhstan dated August 23, 2012 No. 1080.

Seitzer, H., Niemann, D., \& Martens, K. (2021). Placing PISA in perspective: The OECD's multi-centric view on education. Globalisation, Societies and Education, 19(2), 198-212.

Semchenko, A. (2019) Kazakhstan's experience in updating the content of school education (in Russian: Opyt Kazakhstana po obnovleniyu soderzhaniya shkol'nogo obrazovaniya). Collection of scientific articles on materials of the IV International scientificpractical conference "Modern Educational Values and Updating of the Content of Education," pp. 70-76.

Shamshidinova, K., Ayubayeva, N., \& Bridges, D. (2014). Implementing radical change: Nazarbayev Intellectual Schools as Agents of Change. In D. Bridges (Ed.), Educational reform and Internationalisation: the case of school reform in Kazakhstan (pp. 71-82). Cambridge University Press.

Sjøberg, S. (2015). PISA and Global Educational Governance-A critique of the project, its Uses and Implications. Eurasia Journal of Mathematics, Science and Technology Education, 11(1), 111-127. https://doi.org/10.12973/eurasia.2015.1310a

Sorensen, T. B., Ydesen, C., \& Robertson, S. L. (2021). Re-reading the OECD and education: The emergence of a global governing complex-an introduction. Globalisation, Societies and Education, 19(2), 99-107. https://doi.org/10.1080/14767724.2021.1897946

SPESD-State Program of the Education and Science Development of the Republic of Kazakhstan. (2016). State program for 20162019. Approved by the Decree of the President of the Republic of Kazakhstan dated March 1, 2016 No. 205.

SPESD-State Program of the Education and Science Development of the Republic of Kazakhstan. (2019). State program for 2020 2025. Approved by the Decree of the Government of the Republic of Kazakhstan dated December 27, 2019 No. 988.
Sputnik.kz. (2020). I'm a father too: Education minister addresses Kazakh parents. Retrieved 10 July, 2021, from https://ru.sputn ik.kz/education/20200325/13347387/ministr-obrazovaniya-obras chenie-kazakhstanskie-roditeli.html

Starr, K. (2014). The influences and implications of PISA: An Australian perspective. AASA Journal of Scholarship and Practice, 10(4), 19-30.

Takayama, K. (2008). The politics of International league tables: PISA in Japan's achievement crisis debate. Comparative Education, 44(4), 387-407. https://doi.org/10.1080/03050060802481413

Takayama, K., \& Lingard, B. (2021). How to achieve a 'revolution': Assembling the subnational, national and global in the formation of a new, 'scientific' assessment in Japan. Globalisation, Societies and Education, 19(2), 228-244. https://doi.org/10.1080/14767 724.2021 .1878016

Toybazarova, N., \& Nazarova, G. (2018). The modernization of education in Kazakhstan: Trends. Perspective and Problems Bulletin of National Academy of Sciences of the Republic of Kazakhstan, 6(376), 104-114. https://doi.org/10.32014/2018.2518-1467.33

Uljens, M. (2007). The hidden curriculum of PISA: The promotion of neo-liberal policy by educational assessment. In S. T. Hopmann, G. Brinek, \& M. Retzl (Eds.), PISA zufolge PISA-PISA according to PISA (pp. 295-303). Lit Verlag.

Volante, L. (2016). The intersection of International achievement testing and educational policy: Global perspectives on large-scale reform. Routledge Press.

Volante, L., Fazio, X., \& Ritzen, J. (2017). The OECD and educational policy reform: International surveys, governance, and policy evidence. Canadian Journal of Educational Administration and Policy, 184, 34-48.

Waldow, F., \& Steiner-Khamsi, G. (Eds.). (2019). Understanding PISA's attractiveness: Critical analyses in comparative policy studies. Bloomsbury Academic.

Weber, R. (1990). Basic content analysis. Sage.

Winstanley, C. (2010). Writing a dissertation for dummies. Wiley.

Wiseman, A. W., \& Taylor, C. (Eds.). (2017). The impact of the OECD on education worldwide. Emerald.

Yakavets, N., \& Dzhadrina, M. (2014). Educational reforms in Kazakhstan: 'Entering the World Arena'., In D. Bridges (Ed.), Educational reform and Internationalisation: The case of school reform in Kazakhstan (pp. 28-53). Cambridge University Press.

Zhao, Y. (2018). Shifting the education paradigm: Why International borrowing is no longer sufficient for improving education in China. ECNU Review of Education, 1(1), 76-106. https://doi.org/ 10.30926/ecnuroe2018010105

Zhao, Y. (2020). Two decades of havoc: A synthesis of criticism against PISA. Journal of Educational Change, 1(21), 245-266. https:// doi.org/10.1007/s10833-019-09367-x

Zurn, M. (2014). The politicization of world politics and its effects: Eight propositions. European Political Science Review, 6(1), 47-71. https://doi.org/10.1017/S1755773912000276

Publisher's Note Springer Nature remains neutral with regard to jurisdictional claims in published maps and institutional affiliations. 